\title{
First report of Puccinia thaliae on canna lily in New Zealand and in some Pacific island countries
}

\author{
Mahajabeen Padamsee • Eric H. C. McKenzie
}

Received: 4 July 2012 / Accepted: 15 August 2012 / Published online: 27 September 2012

(C) Australasian Plant Pathology Society Inc. 2012

\begin{abstract}
A rust disease was observed on leaves of a cultivated canna lily plant in Auckland, New Zealand in February 2012. Samples were collected and the causal agent determined by morphological and molecular techniques as Puccinia thaliae. This is the first record of $P$. thaliae in New Zealand. The rust is also reported for the first time from several countries in the Pacific islands.
\end{abstract}

Keywords Ornamental plants $\cdot$ Pucciniales $\cdot$ Rust fungi

Canna lily (Cannaceae) is a monocot, herbaceous perennial ornamental plant that is native to tropical South America. Canna lily is a popular garden and landscaping plant in New Zealand and is also widely grown throughout the Pacific. In February 2012, a cultivated canna lily (Canna indica) growing in a residential garden in Auckland was found to be severely infected by a rust fungus. Subsequently, additional rust-infected canna lily plants were identified in Waiheke Island and other locations in Auckland. Samples were collected from the various locations and examined using light microscopy. Diseased samples from all locations exhibited similar symptoms of numerous, yellow, subepidermal, erumpent, and circular to elliptical uredinia on both leaf surfaces. The sori were $<1 \mathrm{~mm}$ in length, often about $0.25 \mathrm{~mm}$ diam. and scattered to clustered, covering the entire leaf. Initially the leaves were covered with uredinia but over the course of a month dark-coloured telia started to develop (Figs. 1-2).

\footnotetext{
M. Padamsee $(\bowtie) \cdot$ E. H. C. McKenzie

Landcare Research,

Private Bag 92170 Auckland, New Zealand

e-mail: padamseem@landcareresearch.co.nz

E. H. C. McKenzie

e-mail: mckenziee@landcareresearch.co.nz
}

The urediniospores (Fig. 3) were variable in shape ranging from subglobose, ellipsoidal, obovoid to pyriform. They measured (23-)26-36(-43)×17-23(-27) $\mu \mathrm{m}$ (av. 30.8× $20.8 \mu \mathrm{m})$, with orange-yellow contents. The wall was thin (1-1.5 $\mu \mathrm{m})$, hyaline and echinulate. The germ pores were obscure, but according to Sivanesan (1970) there are two equatorial pores. Initially, the compact, amber-coloured telia coalesced and developed in a circle around one or more uredinial pustules, mainly on the lower leaf surface but also on the upper surface. Later they were scattered on both sides of the leaf, circular, and $<0.25 \mathrm{~mm}$ diameter. The teliospores (Fig. 4) were elongate-clavate with the lower cell being longer, narrower and paler than the upper cell. They measured $(50-) 60-73(-80) \times(13-) 15-19(-21) \mu \mathrm{m}$ (av. 65.7× $16.4 \mu \mathrm{m})$, with yellow-brown contents. The wall was smooth, yellow-brown, $0.75-1.5 \mu \mathrm{m}$ thick at the sides and $1.5-4 \mu \mathrm{m}$ at the apex, with an apical germ pore. The pedicels were yellow-brown and up to $25 \times 5.5-9 \mu \mathrm{m}$. Pycnia and aecia are not known for $P$. thaliae.

The rust fungus was also examined by molecular methods. Sori were excised and DNA was extracted using an X-tractor Gene System (Corbett Life Science, NSW, Australia). The nuclear ribosomal large subunit (LSU) locus was amplified with a rust-specific primer Rust2inv (Aime 2006) and LR6 (Vilgalys and Hester 1990). A BLAST search of the LSU region returned two sequences of Puccinia thaliae (HQ434482 and EU851154) with $99 \%$ sequence identity over $71 \%$ and $100 \%$ query coverage, respectively. DNA sequences of three collections have been deposited in GenBank [JX206993 (PDD 102350); JX206994 (PDD 83149); JX206995 (PDD 82262)].

Until the late 1950 s/early 1960 s $P$. thaliae was known only from North, South and Central America (Anonymous 1969). It was then reported from Indonesia (Boedijn 1959) and New Caledonia 
Figs. 1-4 Puccinia thaliae: 1. Detail of disease symptom on adaxial leaf surface. 2. Adaxial leaf surface with uredinia and developing telia. 3. Urediniospores (scale bar $=$ $10 \mu \mathrm{m}$ ). 4. Teliospores (scale bar $=10 \mu \mathrm{m})$
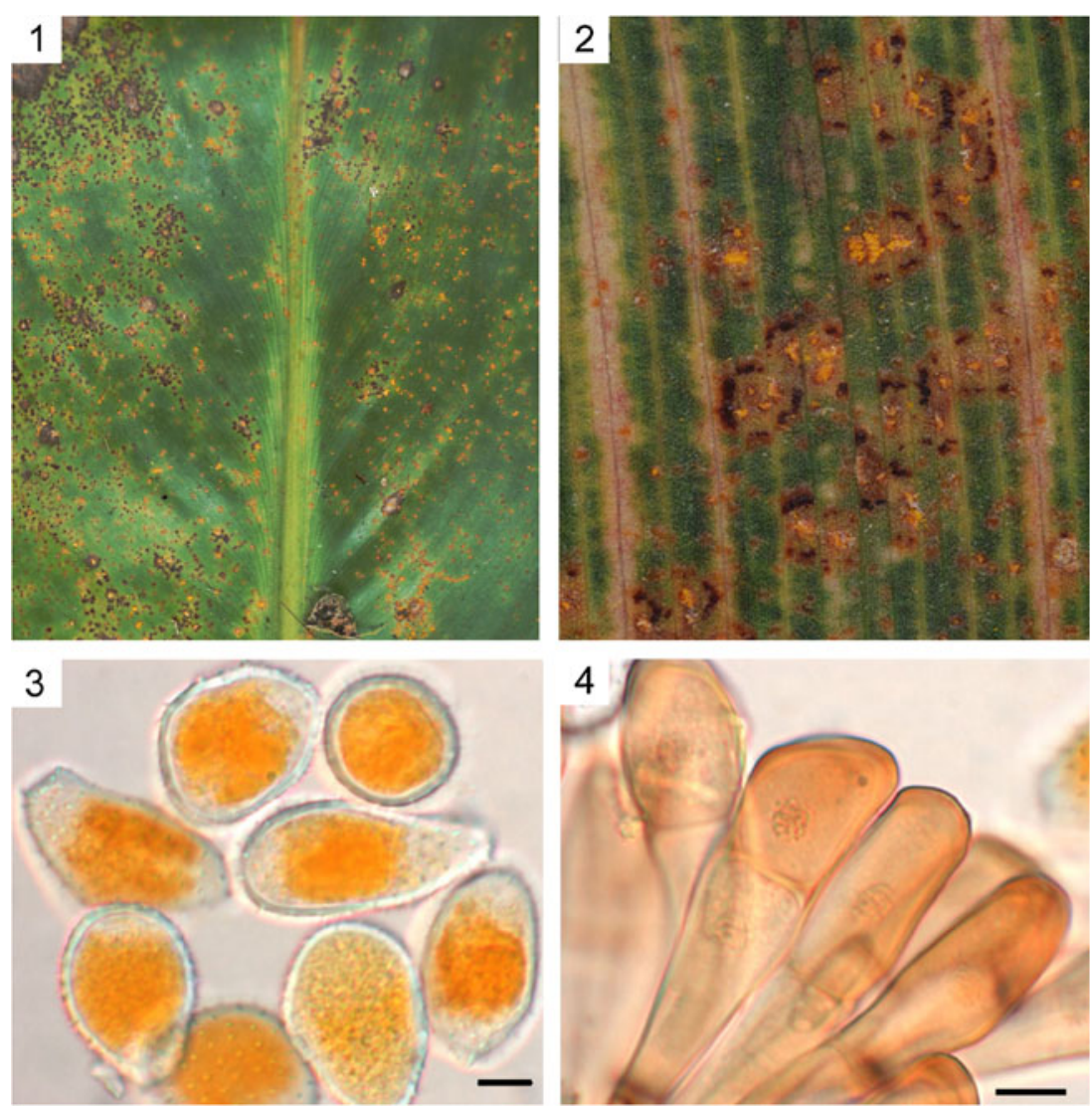

(Mouchacca and Horak 1998 [based on a 1961 collection]). Since the publication of third edition of the CMI Distribution Map No. 224 (Anonymous 1981), the rust has spread to south-east Asia (China, Hong Kong, India, Japan, Singapore, Taiwan, Thailand). It was found in Nigeria in October 1984 (Eboh 1986) and in South Africa in January 2005 (van Jaarsveld et al. 2006) and it has also become widespread within the Pacific. Gardner and Martinez (1985) reported the rust from Hawaii, where it had apparently been seen since the early 1970s. The rust was not found during extensive plant disease surveys in the south Pacific in the 1970s and early 1980s (Dingley et al. 1981), but it was later reported from American Samoa (McKenzie 1996, as $U$. pseudocannae). However, the New Zealand Fungal and Plant Disease Collection (PDD) holds additional specimens of $P$. thaliae from Fiji (first collected 1984), Vanuatu (1996), Solomon Islands (1999), Niue (2000), French Polynesia (2001), Cook Islands (2003), and Palau (2004). Most of the Pacific collections had only uredinia, but one collection from Fiji had telia. Telia were reported from Hawaii (Gardner and Martinez 1985) and Nigeria (Eboh 1986) but not from South Africa (van Jaarsveld et al. 2006). The rust has been reported on numerous species of Canna (Zingiberales, family Cannaceae) as well as on several hosts in the family Marantaceae (Zingiberales): Calathea, Ctenanthe, Ischnosiphon, Maranta, Thalia.

The morphological and molecular analyses confirmed that the rust species is Puccinia thaliae Dietel. This is the first report of $P$. thaliae in New Zealand on canna lily and it is also the first published record of the fungus for several Pacific countries. Voucher materials have been deposited in PDD [New Zealand-PDD 102350, 102438; Cook Islands-PDD 75881, Fiji-PDD 75188; Niue_-PDD 72474; Palau—PDD 82262; Solomon Islands_-PDD 70599; Tonga-PDD 83149; Vanuatu—PDD 66549].

Acknowledgment This research was supported through the Landcare Research Systematics Portfolio, with funding from the Science and Innovation Group of the New Zealand Ministry of Business, Innovation and Employment.

\section{References}

Aime MC (2006) Toward resolving family-level relationships in rust fungi (Uredinales). Mycoscience 47:112-122

Anonymous (1969) Puccinia cannae. Distrib Maps Pl Dis 224 (edn 2): $1-2$

Anonymous (1981) Puccinia cannae. Distrib Maps Pl Dis 224 (edn 3): $1-2$

Boedijn KB (1959) The Uredinales of Indonesia. Nova Hedwigia 1:463-496 
Dingley JM, Fullerton RA, McKenzie EHC (1981) Records of fungi, bacteria, algae, and angiosperms pathogenic on plants in Cook Islands, Fiji, Kiribati, Niue, Tonga, Tuvalu, and Western Samoa. UNDP/FAO/SPEC Survey of Agricultural Pests and Diseases 2. Rome. SPEC, UNDP, FAO. 485p

Eboh DO (1986) A taxonomic survey of Nigerian rust fungi: Uredinales Nigerianensis. IV. Mycologia 78:577-586

Gardner DE, Martinez AP (1985) Occurrence of canna rust (Puccinia thaliae) in Hawaii. Plant Dis 69:1101

McKenzie EHC (1996) Fungi, bacteria and pathogenic algae on plants in American Samoa. SPC Tech Pap 206. 40p
Mouchacca J, Horak E (1998) Annotated checklist of New Caledonian Basidiomycota. II. Rusts and smuts. Mycotaxon 69:13-30

Sivanesan A (1970) Puccinia thaliae. CMI Descr Pathol Fungi Bacteriol 267:1

van Jaarsveld LC, Kriel W-M, Minnaar A (2006) First report of Puccinia thaliae on canna lily in South Africa. Plant Dis 90:113

Vilgalys R, Hester M (1990) Rapid genetic identification and mapping of enzymatically amplified ribosomal DNA from several Cryptococcus species. J Bacteriol 172:4238-4246 